\title{
Gregory Forgues
}

\section{Charting the Geographies of 'Ju Mi pham rnam rgyal rgya mtsho's Perspectivist Approach to the Two Truths}

\begin{abstract}
'Ju Mi pham rNam rgyal rGya mtsho' is considered one of the greatest scholars of the rNying ma tradition of Tibetan Buddhism. He is well known for his original and somewhat innovative presentation of Madhyamaka, which integrates both Candrakīrti's tradition and Sāntarakșita's philosophical legacy. ${ }^{2}$ Two-thirds of Mipham's (1846-1912) works concern subjects related to philosophical topics such as epistemology, ontology, and metaphysics. ${ }^{3}$ Although he did not shy away from intellectual confrontation and debate on more than a few occasions, ${ }^{4}$ he is first and foremost known for his inclusivist ${ }^{5}$ interpretation of Buddhist doctrines. ${ }^{6}$ In this paper, I will focus on his interpretation of the two truths (bden
\end{abstract}

1 Hereafter Mipham, unless his name is transliterated in Wylie (i.e. 'Ju Mi pham rNam rgyal rGya mtsho) or quoted from an author following a different transliteration of Mipham's name (e.g. Mi-pham, Mipam, etc.).

2 For biographical details on Mipham's life, see Dieter Schuh, Tibetische Handschriften und Blockdrucke sowie Tonbandaufnahmen tibetischer Erzählungen, vol. 11.5 (Wiesbaden: Franz Steiner Verlag, 1973); Steven D. Goodman, "Mi-pham rGya-mtsho: An Account of his Life, the Printing of his Works, and the Structure of his Treatise Entitled mkhas-pa'i tshul la 'jug pa'i sgo," in Wind Horse, ed. Ronald M. Davidson (Fremont: Jain Publishing Company, 1981), 59-78; John W. Pettit, Mi pham's Beacon of Certainty: Illuminating the View of Dzogchen, the Great Perfection (Boston: Wisdom, 1999), 1ff.; Gene E. Smith, Among Tibetan Texts, History \& Literature of the Himalayan Plateau (Boston: Wisdom, 2001), 230-231; Douglas S. Duckworth, Jamgön Mipam: His Life and Teachings (Boston: Shambhala, 2011).

3 See Karma Phuntsho, "Ju Mi pham rNam rgyal rGya mTsho. His Position in the Tibetan Religious Hierarchy and a Synoptic Survey of his Contributions," in The Pandita and the Siddha, Tibetan Studies in Honour of E. Gene Smith, ed. Ramon N. Prats (Dharamsala: Amnye Machen Institute, 2007), 191-209 for a presentation of Mipham's main works.

4 See Markus Viehbeck, Polemics in Indo-Tibetan Scholasticism: A Late 19th-Century Debate between 'Ju Mi pham and Dpa' ris Rab gsal (Vienna: Wiener Studien zur Tibetologie und Buddhismuskunde, 2014).

5 This term refers to the work of Indologist Paul Hacker on the notion of "inclusivism"; see Paul Hacker, "Inklusivismus," in Inklusivismus: Eine indische Denkform, ed. Gerhardt Oberhammer (Vienna: Institut für Indologie der Universität Wien, 1983), 11-28. Inclusivism denotes the tendency to integrate central concepts and ideas from another religious tradition into one's own approach.

6 See for example Pettit, Mi pham's Beacon of Certainty, 6; Karma Phuntsho, Mi pham's Dialectics and the Debate of Emptiness (New York: RoutledgeCurzon, 2005), 8, 15, 207, 211.

○ Open Access. () 2020 Gregory Forgues, published by De Gruyter. (cc) BY-NC-ND This work is licensed under a Creative Commons Attribution-NonCommercial-NoDerivatives 4.0 International License. https://doi.org/10.1515/9783110557176-009 
gnyis, satyadvaya), ${ }^{7}$ namely, the "concealing" (kun rdzob, samvrtit) ${ }^{8}$ and the "ultimate" (don dam pa, paramārtha). ${ }^{9}$

In his monograph investigating the Tibetan hermeneutical debate on the two truths, Sonam Thakchoe notes that Mipham's treatment of the subject appears contradictory. He considers Mipham's discourse as ambiguous, since Mipham seems to both endorse and criticize Tsong kha pa's (1357-1419) position. ${ }^{10}$ More importantly, Thakchoe remarks that Mipham propounds contradictory doctrines on the nature of the relationship between the two truths. ${ }^{11}$ Reading Thakchoe, one is left with the impression that Mipham's position on the matter is rather inconsistent. The fact that Mipham also describes the relationship between the two truths in terms of "unity" (zung 'jug, yuganaddha) could only, from Thakchoe's point of view, aggravate the charge of philosophical inconsistency. Thakchoe's reading of Mipham therefore raises an important question: does Mipham's position entail contradictions? And if not, how are we to make sense of his discourse on the two truths?

Phuntsho was the first to identify Mipham's various doctrinal positions in his treatment of the relationship between the two truths. ${ }^{12}$ Duckworth has also noted the presence and importance of various perspectives in Mipham's writings. ${ }^{13}$ Finally, Wangchuk has stressed the centrality of the term zung 'jug ("unity")

7 Technical terms are given in Tibetan and Sanskrit (when available).

8 I translate kun rdzob as "concealing" in accordance with the Sanskrit etymology of the word samvrti. For a detailed analysis of this term in Mipham's presentation of the two truths, see point 2 below.

9 The two truths represent a didactic model commonly found in Buddhist literature. This model distinguishes two levels of truth in order to present the nature of our reality.

10 Sonam Thakchoe, The Two Truths Debate (Boston: Wisdom, 2007), 176, n. 58. Tsong kha pa is the founder of the dGe lugs school of Tibetan Buddhism, one of the four schools of Tibetan Buddhism. The numerous theoretical complexities induced by Mipham's perspectivist interpretation of the two truths has been the subject of fierce debate between Mipham and dGe lugs scholars. On this occasion, dGe lugs scholars disputed several points, among which the inseparability (zun 'jug) of the two truths as expounded by Mipham. For an analysis of the polemical literature produced by these debates, see Viehbeck, Polemics in Indo-Tibetan Scholasticism.

11 See Thakchoe, The Two Truths Debate, 180. Thakchoe sees Mipham as accepting both that the two truths are incompatible (i.e., gcig pa dkag pa'i tha dad, "different in the sense that their identity is negated"), and that they have a single ontological identity but different conceptual identities (ngo bo gcig la ldog pa tha dad, "different conceptual distinguishers with regard to a single entity").

12 See Phuntsho, Mi pham's Dialectics and the Debate of Emptiness, 123.

13 See for example Duckworth, Mipam on Buddha Nature (Albany: State University of New York Press, 2008), 138. 
in Mipham's discourse on the two truths. ${ }^{14}$ These excellent publications on Mipham's interpretation of Madhyamaka have not, however, systematically addressed the issues raised by Thakchoe in 2007. Phuntsho's contribution was published before Thakchoe even identified the issue, while Duckworth's Mipam on Buddha Nature was written at roughly the same time.

In this paper, I show that Mipham sees any informed knowledge on the nature of reality as perspectival and expressed to address a specific soteriological concern. According to his view, discourses on the relationship between the two truths are soteriologically situated. Mipham's presentation of Madhyamaka can therefore be seen as perspectivist insofar as Mipham considers the validity of doctrines on the two truths as dependent on the soteriological context within which these doctrines are formulated. This inclusivist approach results in a complex presentation of Madhyamaka in which several seemingly contradictory positions are ranked according to an ascending scale of views. To answer Thakchoe's questions, it is therefore essential to examine in detail the cognitive and epistemic standpoints from which Mipham expounds the two truths in his writings on the subject. ${ }^{15}$

\section{A Perspectivist Approach to the Two Truths}

As noted by Tibetan and Western scholars alike, Mipham uses two distinct definitions of the two truths to ascertain the view (lta ba, drșți). ${ }^{16}$ The first definition is based on the distinction between appearance (snang ba) and emptiness (stong pa), whereas the second hinges on the concordance, or

14 See Dorji Wangchuk, “Was Mi-pham a Dialectical Monist? On a Recent Study of Mi-pham's Interpretation of the Buddha-Nature Theory," Indo-Iranian Journal 55 (2012): 15-38.

15 Mipham's view on the two truths, as found in his Collected Works (Mi pham gsung 'bum), did not evolve through time. His doctrinal positions are remarkably stable from the moment he started composing commentaries and original works. In addition to primary sources, I also consulted the monographs and articles mentioned in the bibliography below. Key statements drawn from Mipham's works found in some of these publications were retranslated from the Tibetan for the present article.

16 See for example Duckworth, Mipam on Buddha Nature, 6ff.; Duckworth, Jamgön Mipam: His Life and Teachings, 13; Phuntsho, Mi pham's Dialectics and the Debate of Emptiness, 114ff.; Markus Viehbeck, "Fighting for the Truth - Satyadvaya and the Debates Provoked by Mi pham's Nor bu ke ta ka," Journal of the International Association of Buddhist Studies 34, no. 1-2 (2011): 291-320; Wangchuk, “Was Mi-pham a Dialectical Monist?” 24; Viehbeck, Polemics in Indo-Tibetan Scholasticism, 151, n. 207. 
lack thereof, between the way things are (gnas lugs) and the way they appear (snang lugs). In the $d B u$ ma rgyan gyi rnam bshad, his commentary on Sāntarakșita's Madhyamakālaṃkāra, one of his most personal philosophical works, Mipham declares ${ }^{17}$ :

Moreover, in [all the Buddha's] words ( $\left.b k a^{\prime}\right)$ and treatises (bstan bcos, śāstra), there are two ways to posit the two truths: (1) From the perspective of a valid cognition investigating the ultimate, namely, the way [things] are (gnas lugs), the "ultimate" refers to emptiness (stong $p a$ ) and the "concealing" to appearances (snang ba); (2) From the perspective of a conventional (kun tu tha snyad) valid cognition investigating the mode of appearance [of things] (snang tshul), the "ultimate" refers to the subject and object for which nature and appearance (gnas snang) are in irrefutable accordance. The "concealing" refers to the opposite. ${ }^{18}$

According to Mipham, the first definition - termed snang stong - is usually encountered in Prāsangika Madhyamaka or in the sūtras of the Second Turning of the Wheel that explicate the absence of "own-nature" (ngo bo nyid, svabhāva) of phenomena. The second definition is prevalent in the Maitreya tradition and the sūtras of the Third Turning of the Wheel. The latter is also referred to as the mthun mi mthun ("accordance/discordance") model, since the distinction between the two truths depends upon whether the way things appear is concordant with the way things are. As a consequence, the first definition (snang stong) could be considered to be apophatic, being based on the ultimate analysis of appearances showing their absence of "own-nature." The second definition (mthun mi mthun) implies a more cataphatic approach to the ultimate through the distinction it establishes between the sphere of mind (sems) that constitutes the concealing truth and gnosis (ye shes), the ultimate. In Mipham's system, this second definition is used to explain that the nature of a buddha (tathāgatagarbha) is empty of adventitious afflictions (nyon mongs, kleśa), but not empty of buddha qualities; in other words, to teach the difference between the conditioned mind and gnosis, which cannot be reduced to a blank nothingness. One should add that these two definitions of the truths are not mutually

17 For a summary of this point, see gZhan stong khas len seng ge'i nga ro in Pettit, Mi pham's Beacon of Certainty, 416, and Duckworth, Mipam on Buddha Nature, 6-20, about the use of the second definition of the two truths in the context of Mipham's interpretation of the tathāgatagarbha theory; cf. Phuntsho, Mi pham's Dialectics, 114-16.

18 dBu ma rgyan gyi rnam bshad, 30, 3: de'ang bka' dang bstan bcos rnams na bden gnyis 'jog tshul gnyis su gnas te/ gnas lugs don dam la dpyod pa'i tshad ma’i dbang du byas te/ stong pa la don dam dang/snang ba la kun rdzob ces bzhag pa dang/snang tshul la dpyod pa kun tu tha snyad pa'i tshad ma’i dbang du byas te/ gnas snang mthun pa mi bslu ba'i yul dang yul can la don dam dang/ ldog phyogs la kun rdzob tu 'jog pa'i tshul gnyis las/ 
exclusive, since gnosis is considered to be without an "own-nature," although it does possess qualities.

From the viewpoint of rDzogs chen, the highest teaching in Mipham's tradition, the first definition of the two truths appears to be formulated from an ontological perspective, stressing the primordially pure ( $k a$ dag) aspect of reality, whereas the second definition seems to be expressed from a cognitive perspective conducive to the realization of the spontaneously present (lhun grub) aspect of reality. The propaedeutic function of this perspectival approach plays a central role in the way Mipham teaches Madhyamaka as a doctrine that facilitates the realization of rDzogs chen. In his introduction to the $d B u$ ma rgyan gyi rnam bshad, he thus clearly differentiates the context in which statements about the ultimate are made and explains at length that there are no contradictions between different views insofar as one understands that the multiplicity of apparently divergent opinions on a given topic reflects the various contexts in which these views are formulated.

This hermeneutic strategy based on the notion of standpoint and perspective is often used by Mipham to avoid contradictions, but it is also profoundly reflective of his understanding that doctrines, as expressions of a truth, are related to a specific epistemic context. To illustrate this point, I would like to turn to Mipham's first definition of the two truths, in which the standard opposition between appearance and emptiness is resolved in a way that is similar to Go rams pa's approach: ${ }^{19}$

With regard to those [two truths], the concealing truth represents all phenomena (chos, dharma) in whatever way they appear: the ground comprised of the conditioned and the unconditioned, [such as] the aggregates (phung po, skandha), the basic constituents (khams, dhātu), and the sources of cognition (skye mched, āyatana); the path, [for example,] the perfections, the factors conducive to awakening (byang chub kyi phyogs, bodhipakșa), etc.; and the fruit, [such as] the ten powers and so forth. In brief, [the concealing truth includes] the innumerable phenomena, as many as they are (ji snyed pa), all that is posited from the perspective of the incontrovertible (bslus med) mode of appearance of cognitive objects.

With regard to the ultimate truth, the phenomena of the ground, path, and fruit abide within the emptiness that is not established as anything at all. This [mode of abiding], being posited from the perspective of the way things are (gnas lugs), is the profound phenomenon (chos, dharma) as it is (ji lta ba).

19 See José Ignacio Cabezón and Geshe Lobsang Dargyay, trans., Freedom from Extremes, Gorampa's "Distinguishing the View" and the Polemics of Emptiness (Boston: Wisdom, 2007), 207-11. 
Realizing that these two [truths] are in the real sense in a state of unity (zung 'jug) or fundamental sameness (mnyam pa nyid) is the supreme object of realization, the ultimate purpose. $^{20}$

In this apparently basic definition of the two truths, a central point is made. Each truth corresponds to an object that is dependent on an epistemic perspective. The dividing line between those truths is, by way of consequence, not so much the concealing and ultimate objects in themselves, but the way things are perceived. In his Nor bu ke ta ka, while commenting on Sāntideva's Bodhicaryāvatāra (BCA IX.2), Mipham thus quotes Candrakīrti's Mādhyamakāvatāra (Mav VI, 23):

By perceiving correctly or incorrectly all things,

The two natures of all things will be apprehended [. . . $]^{21}$

\section{The Concealing Truth as an Epistemic Perspective}

As explained by Mipham in the quote above, the concealing truth is "what is posited from the perspective of the incontrovertible mode of appearance of all cognitive objects." Objects are mere experiences, appearances, manifestations (snang $b a$ ). The concept of "truth" is clearly conceived here in epistemic terms rather than as a purely ontological issue. In Mipham's explanation, the concealing truth consists merely of mistaken experience. Mipham thus declares in his Nor bu ke ta ka,

[. . .] although the concealing truth is devoid of arising and so on, in its nature, it is that which appears as that (der snang), a mode of appearance similar to an illusion, a dream, or a hair [appearing to someone suffering from myodesopsia]. ${ }^{22}$

20 Mkhas pa'i tshul la 'jug pa'i sgo, Vol.II, 174: de la kun rdzob kyi bden pa ni ji ltar snang ba'i chos gzhi 'dus byas dang 'dus ma byas kyis bsdus pa phung khams skye mched dang / lam phar phyin dang byang phyogs sogs dang/ 'bras bu stobs bcu la sogs pa mdor na shes bya rnams kyi snang tshul bslus med kyi ngos nas bzhag pa ji snyed pa rgya che bäi chos so/ don dam bden pa ni gzhi lam 'bras bu'i chos de dag rang bzhin cir yang ma grub pa'i stong pa nyid du gnas pa ni gnas lugs kyi ngos nas bzhag pa ste ji lta ba zab mo’i chos so/ de gnyis yang dag pa'i don du zung 'jug mnyam pa nyid du rtogs pa ni rtogs bya rnams kyi nang na mchog tu gyur pa mthar thug gi don no/

21 For the Sanskrit, see Xuezhu Li, “Madhyamakāvatāra-kārikā,” China Tibetology 1 (2012): 5: samyagmṛ̦ādarśanalabdhabhāvaṃ rūpadvayaṃ bibhrati sarvabhāvāḥ.

22 Nor bu ke ta ka, 4: de la kun rdzob ni skye sogs kyi rang bzhin du med bzhin der snang sgyu ma dang rmi lam skra shad lta bu'i snang tshul 'di yin la/ 
A correct understanding of the compound lexeme der snang ba is required to grasp Mipham's understanding of concealing truth. As is characteristic of Buddhist polysemic technical terms, snang ba is translated in various ways: it is generally assumed to mean "appearance," "perception," "manifestation," or "experience." I have chosen to translate it as "appearance" in the sense of the manifestation as an experience. The notion of experience here conveys the idea of subjectivity, while the idea of manifestation expresses the dynamic aspect of snang ba. Unfortunately, these two aspects are somewhat missing when one translates snang ba with "appearance." An appearance is usually understood as belonging to an external object and a perception as something purely subjective. The notion of appearance in the sense of a cognitive event supports a gradual shift from the perspective of the concealing truth experienced by ordinary beings up to the perspective of sublime beings ('phags pa rnams), a method that is the whole point of Mipham's propaedeutic approach to the two truths. The term does not aim here at reinforcing any dualistic ontological identification of the concealing in terms of subject/object, which is the mark of lower substantialist systems. We can therefore safely understand der snang ba as meaning "that which appears there" in the sense of "an appearance as this or that in [one's] mind." With this expression, Mipham refers to a cognitive process without implying that appearances exist ultimately as mind itself, that is to say, without substantially (rdzas su, dravyatas) positing any existence, on the side of the subject or the object. In his commentary to the $d B u$ ma rgyan, he explains, ${ }^{23}$

One fully knows how things are conventionally by accepting that the various appearances are magical manifestations (rnam par 'phrul pa, vikurvāna), and [one thus] acquires confidence in the way [one] enters in or turns away from samsāra. Further, from the perspective of the way things are, which is free from all objective supports (dmigs pa, älambana), marks, and mental proliferations, it is not even observed that "appearance is mind." However, this is the ultimate that is beyond conventional designations. [53] Within the

23 My preference would be to translate snang ba with "manifestation of an experience," which has the advantage of not committing oneself to either of the two alternatives of the subject/object dichotomy while maintaining the dynamic notion snang ba carries. However, I have settled for "appearance," which, being much shorter, leads to a more concise translation of this term. In the context of rDzogs chen, this term facilitates the right understanding of the expressive power ( $r t s a l$ ) of awareness (rig pa) or even of nyams, the temporary shifting experiences during practice that belong to mind and not to rig $p a$. As Mipham has based his exposition of Madhyamaka on a gradual progression towards the view of rDzogs chen, I believe that it is important to remain in the spirit of this tradition when translating these technical terms in order to allow for a smooth transition between the different levels of Mipham's ascending scale of philosophical views. 
context of the appearance of conventional designations, the existence of external objects is refuted by reasoning, while it is established through reasoning that this [appearance] is nothing but mind. ${ }^{24}$ As a consequence, insofar as a conventional designation is accepted without contradicting confined perception (tshur mthong), there is no better [account of the concealing] than this. If one examines the phenomena that are merely posited through the power of conceptuality, [one finds that] they are not established as anything at all. However, these unceasing and incontrovertible appearances, which are experienced from one's point of view, are established by the power of the things themselves as mental appearances or one's own appearances. ${ }^{25}$

For Mipham, the concealing truth is thus nothing but this multiplicity of experiences manifesting in the mind. He justifies this view by stressing that since such a presentation is in accord with empirical perceptions, there is no better way to define the concealing truth. However, these experiences are not mind, a significant point made by Klong chen pa that Mipham undeniably accepts. ${ }^{26}$

24 Mipham does not mean hereby that things are mind, but only that they appear "there" (i.e., in the mind). They are information in the forms of ideas, notions, and various types of cognitions. Their substance, however, is neither matter nor mind. His remark is purely epistemic. This way of positing the concealing truth is reminiscent of the Maitreya chapter of the SNS (SNS 6). Klong chen pa also understands snang ba in the same way: "Notons de plus que Klong chen pa feint aussi souvent de tenir l'esprit pour le spectateur des apparences, celui qui en juge, tandis qu'en même temps il est clair que les apparences ne sont rien de plus que ce fait pour lui de les percevoir. On demandera pourquoi il prétend ainsi distinguer l'esprit des apparences; c'est qu'il décrit une structure 'apparaître-à-l'esprit', dont les moments sont indissociables, mais en même temps ne sont possibles que pour autant qu'ils paraissent autonomes. Qu'est-ce-à dire? Le mot 'snang $b a$ ' doit, comme on l'a dit, s'interpréter comme le 'paraître' (comme processus) et en même temps comme le contenu qualifié de cette apparition”; see Stéphane Arguillère, "Le Repos de l'esprit, la question de voie graduée dans le rDzogs pa Chen po selon quelques oeuvres de Klong chen Rab 'byams" (MA thesis, Paris: 1991), 40. As rightly remarked by Arguillère, snang $b a$ denotes both the process and its content.

25 dBu ma rgyan gyi mam bshad, 52.5ff.: gsum pa snang ba sna tshogs pa sems kyi rnam 'phrul du khas blangs pas tha snyad kyi yin lugs mthar thug pa shes shing 'khor bar 'jug ldog gi tshul la yid ches thob ste/ de la dmigs mtshan spros pa thams cad dang bral ba'i gnas lugs kyi dbang du na/ snang ba sems yin no zhes kyang mi dmigs mod/ de ni tha snyad las 'das pa'i don dam pa yin la/ [53] tha snyad snang ba'i ngang tshul 'di la gnas ni/ phyi don yod pa la rigs pas gnod cing/ sems tsam yin pa la rigs pa'i sgrub byed yod pas tshur mthong gis las ma brgal bar tha snyad zhig khas len na 'di las gong du gyur pa med de/ rtog pa'i dbang gis bzhag pa tsam gyi chos rnams dpyad na gang du'ang ma grub kyang/ rang ngor myong tshul gyis bslu med du snang ba 'gog tu med pa 'di sems kyi snang ba'am rang snang tsam du dngos po'i stobs kyis grub pa yin no/

26 In his presentation of Mañjuśrīmitra's rDo la gser, Lipman shows that, in the Yid bzhin mdzod, Klong chen pa insists that snang ba has no substratum: "Nowadays, ignoramuses say that rDzogs chen claims that how things appear is merely our own mind. This is totally unacceptable, for it leads to the absurd conclusion that mind can be divided into parts, colours, and qualities you can get a hold on, since the way things appear seems to be so. [. . .] However, we 
As a consequence, these appearances are not declared to be mind in any ontological sense. In a word, when Mipham defines the concealing truth as experiences manifesting in the mind, he does not imply that the essence of appearances is nothing but mind (cittamätra) in the way of an idealist reductionism. His view is not that mind has a higher ontological status than other phenomena on the level of the concealing truth. In fact, Mipham's presentation of the concealing simply describes an epistemic process that does not entail any assertion of existence as such. Ascribing an ultimate substance to illusion is not the point. Rather, the point is that delusion as a cognitive event takes place from a purely epistemic perspective. These manifestations of various experiences, these appearances, are seen as "the play of mind," even at the level of the sūtras, which, in the perspective of higher teachings such as rDzogs chen, can subsequently facilitate a gradual transition from a lower (i.e., provisional) understanding of the concealing to a more profound one, as found in the context of the unity (zung 'jug) of the two truths:

Thus, when one knows that appearances are the play of mind, [one has] a way to find certainty as to how one engages in or turns away from samsāra. ${ }^{27}$

Conditioned ('dus byas, samskrta) phenomena are seen by Mipham as nothing but experiences manifesting in the mind, and represent a dualistic cognitive process. ${ }^{28}$ Mind is identified as delusion, not as the ultimate, from the perspective of ordinary beings, which echoes rDzogs chen's distinction between dualistic mind (sems) and nondual awareness (rig pa). Mipham's approach allows

maintain that how things appear is without root or basis, occasioned by the intoxicant of the deluding habituating tendencies making themselves felt in experience. Therefore, we are those who say that there is no actuality to how things appear." See Kennard Lipman and Namkhai Norbu, Primordial Experience (Boston: Shambhala,1986), 21; further, "Since all the configurations of events/meanings that present themselves to us as the five sense objects of visible form, and so forth, as well as the whole outer world and the beings it contains, are present in mind, they are not something apart from mind. Although they seem to be something other than mind, since they are actually nonexistent, like a dream or conjurer's illusion, they can't be found as something apart from mind. Also, for this reason, they can't be identified with mind itself, as illustrated by the eight similes of conjurer's illusion, and so forth. Examining the ultimate components, whether individual or composite, of material objects that, although they are nothing at all, are clearly experienced, shows that either way they are just the same in that there is nothing that makes them what they are" (Lipman, Primordial Experience, 22-23; I use "mind" instead of Lipman's “experience” for sems).

27 dBu ma rgyan gyi rnam bshad, 53.4ff.: de ltar snang ba sems nyid kyi rol par shes na 'khor bar 'jug ldog gi tshul la nges pa rnyed tshul yang/

28 See Pettit, Mi pham's Beacon of Certainty, 155. 
him to refer to this distinction through his second definition of the two truths, corresponding to the concordance/discordance (mthun mi mthun) model. ${ }^{29}$

Putative objects are consequently reduced merely to the vast field of experiences and appearances occurring in the mind as being real, although they are not. As stated in Mipham's commentary on the Dharmadharmatāvibhāga:

That which is designated as "phenomenon" in the immediately preceding explanation, the character (mtshan nyid, lakșana) of samssāra itself, appears dualistically as an apprehending subject or an apprehended object. Then, inasmuch as this appearance is grasped as this or that and designated by various expressions, this dualistic appearance of an apprehended object and an apprehending subject, being an appearance, is not truly established, just like the perspective of a drawing that appears to exist. ${ }^{30}$ Therefore, like the appearance of strands of hair and so forth [for someone suffering of myodesopsia], it is nothing but one's own incorrect projection (kun tu rtog pa, parikalpa), since it appears in [one's] mind in the manner of a nonexistent object. ${ }^{31}$

According to Mipham, the concealing truth is a perspective that takes as an existing object that which does not exist. If this object is analyzed, nothing is found. But since ordinary beings experience something, this level of ordinary reality is etymologically termed “concealing” (kun rdzob, samvrti). Mipham’s explanations in the Nor bu ke ta $k a$ and in the $d B u$ ma rgyan gyi rnam bshad follow those of Prajñākāramati’s ad BCA 2a-b here ${ }^{32}$ :

Because the so-called "concealing [truth]" appears as arising and so forth, emptiness is hidden from the perspective of spiritually immature persons and must be exclusively understood as that which has become veiled (bsgribs pa). ${ }^{33}$

29 On the distinction between sems and ye shes in rDzogs chen, see David Higgins, The Philosophical Foundations of Classical rDzogs chen in Tibet: Investigating the Distinction between Dualistic Mind (sems) and Primordial Knowing (ye shes) (Vienna: Wiener Studien zur Tibetologie und Buddhismuskunde, 2013).

30 Cf. Mahāyānasūtrālaṃkara, XIII, 17ab, where the same simile is found: yathaiva citre vidhivad vicitrite natonnatam nāsti ca dṛ́syate 'tha cal

31 Ye shes snang ba, 615.3: bshad ma thag pa de la chos zhes brjod pa 'khor ba de nyid kyi mtshan nyid ni/ gzung 'dzin gnyis su snang ba dang/ ji ltar snang ba de 'di dang de ltar zhen cing ming sna tshogs kyis mngon par brjod par snang ba can 'di nyid de/ 'di ltar tshul bzhin bris ba'i ri mo la ma thod man med kyang yod par snang ba ltar gzung 'dzin gnyis su snang ba de ni/ snang ba ltar don lam grub bas na dper na skra shad la sogs par snang ba bzhin du yang dag pa ma yin pa'i rang gi kun tu rtog pa tsam/ yul med bzhin tu sems la snang ba'i phyir ro/

32 See P. L. Vaidya, Bodhicaryāvatāra of Śāntideva with the Commentary Pañjikā of Prajñākaramati (Dharbhanga: Mithila Institute, 1960), 176, lines 4-11.

33 dBu ma rgyan gyi rnam bshad, 30.6ff.: kun rdzob ces skye ba sogs su snang ba’i tshul gyis byis pa rnams kyi ngor stong pa nyid spas shing bsgribs par gyur pa lta bu zhig kho na la go dgos kyil 
In this statement, Mipham does not present the concealing truth as intrinsically different from the ultimate, but as that which has become concealed, obstructed, covered, veiled (samvrti) "from the perspective of spiritually immature beings." This latter remark might seem innocuous, but it is an essential point in Mipham's discernment of various perspectives in accordance with Sāntarakṣita’s approach, particularly in the context of a discourse on the ultimate.

\section{The Ultimate Truth ... from the Perspectives of the Concealing and the Ultimate Truths}

In his commentary on $B C A 2 \mathrm{a}-\mathrm{b}$, Mipham mentions two ultimates: the nominal (rnam grangs pa'i don dam, *paryāyaparamārtha) or concordant ultimate (mthun pa'i don dam) and the actual ultimate (rnam grangs min pa'i don dam, *aparyāyaparamārtha). The nominal ultimate is defined as "the mere ultimate nonexistence of all substantial things." The actual ultimate is on its part defined as "freedom from the four extremes." According to Mipham (cf. Nor bu ke ta ka ad BCA $2 \mathrm{a}-\mathrm{b}$ ), pretending that things exist conventionally but are ultimately nonexistent is acceptable from the perspective of beginners, but is definitely limited from the perspective of sublime beings. Here again, the ultimate is explained from the perspective of the essence, since, as explained by Kapstein, this division prevents one from conflating the discourse about the absolute with its realization. ${ }^{34}$ According to Mipham, the nominal ultimate is therefore nothing more than a pedagogical device that is simply in accordance with the actual ultimate: ${ }^{35}$

\footnotetext{
Likewise, at the beginning, conventional arising and ultimate nonarising [of phenomena], as objects of language and conceptuality at the time of hearing and reflecting are established together within a twofold system [i.e., the two truths]. As one member of this pair, the nominal ultimate is [called] nominal because it is a conceptualization of the ultimate, and it is derived from the opposite pair member with which it is associated (i.e., concealing [truth]). The nominal, the opposite of the concealing within the so-called two truths, is the cause [of the understanding of the actual ultimate]. It is merely an entrance gate leading to the consummate ultimate (don dam mthar thug). ${ }^{36}$
}

34 See Kapstein, Reason's Traces (Boston: Wisdom, 2001), 329.

35 See Viehbeck, "Fighting for the Truth."

36 dBu ma rgyan gyi mam bshad, 34.5ff.: de ltar dang por thos bsam gyi sgra rtog gi yul du gyur pa'i tha snyad du skye ba dang/ don dam par mi skye ba lta bu tshul gnyis zung du bzhag pa'i ya gyal rnams grangs pa’i don dam ni/ kun rdzob yod pa’i zlas drangs pa’i phyir ram/ don dam 
If the ultimate beyond all mental proliferations is stated in the form of a nonaffirming negation, then some unfortunate consequences ensue. Mipham uses a typical reductio ad absurdum here:

Without the two investigations of the ultimate, The unity (zung 'jug) of the two truths would not be known. ${ }^{37}$

As the ultimate would fall into the extreme of mental proliferations, It would namely, itself, destroy its own nature. ${ }^{38}$

Already in his $d B u$ ma rgyan gyi rnam bshad, Mipham seems to be honestly concerned that such a way of stating the ultimate might lead to the wrong understanding:

If this alone, [namely that the ultimate truth means nonexistence], is taught as the ultimate, some people of weak understanding would think, "Nonexistence only, which is the negation of the negandum, is the [ultimate] nature [of phenomena]." Clinging to emptiness, they would become incurably attached to this view [of emptiness]. This clinging is of two kinds: the clinging to emptiness as something substantial and the clinging [to emptiness] as something insubstantial. ${ }^{39}$

In the following statement, Mipham shows that sheer nonexistence alone is indeed nothing but conceptuality in disguise. ${ }^{40}$ It is not to be confused with the freedom from extremes that corresponds to what could prosaically be termed a mystical experience beyond the range of our ordinary cognitive processes:

Thus, owing to the clinging to substantial things (dngos po, bhāva) as being existent, which has been a habit since beginningless time, [phenomena] are established as nonexistent and one is made familiar with [this]. If one does not understand that the nature of [any seemingly] substantial thing is nonexistent, the certainty regarding the nature of phenomena, which is beyond extremes, cannot arise. However, this pure nonexistence alone (med pa nyid tsam kho na) is not the consummate nature of phenomena. At the time when this substantial thing that is investigated and about which it is said "No substantial thing such as form and so forth exists" is conventionally not perceived as arising

pa’i grangs su gtogs pas na rnam grangs te/ bden pa gnyis zhes pa’i kun rdzob kyi zlar bgrang rgyud de yin la/ de ni don dam mthar thug dang mthun pa'i sgo tsam mam/

37 The first verse refers to the nominal and the actual ultimates.

38 Shes rab ral gri, 804.3ff.: /don dam dpyod byed gnyis med na//bden gnyis zung 'jug mi shes shing//don dam spros pa'i mthar lhung la//de yang rang gis rang nyid 'jig/

39 dBu ma rgyan gyi mam bshad, 55.5ff.: de tsam zhig don dam du bstan na ni blo chung ba gcig dgag bya bkag pa'i med pa tsam gnas lugs so snyam du stong pa nyid la zhen nas dsor mi rung ba'i lta bar 'gyur la/ zhen tshul la'ang stong nyid la dngos por zhen pa dang dngos med du zhen pa gnyis yod/

40 On the three types of conceptuality (sgra don 'dzes 'dzin gyi rtog pa, ngo bo nyid kyi rtog pa, rtsing zhib kyi rtog pa), see Phuntsho, Mi pham's Dialectics, $190 \mathrm{ff}$. 
and so forth on the basis of its own essence, how could [this nonexistence of a substantial thing] then be the intellect's object of reference, since the very nonexistence of [any] substantial thing that depends on this [substantial thing] (de la brten) has no substantial thing it can relate to? It is impossible, just like the death of the unborn son of a barren woman is not perceived. Thus, nonexistence does not exist, as it is only posited in dependence upon existence, namely, that which is established by its own essence as independent.

Some say, "Well, by negating existence, nonexistence is established. If in turn you negate nonexistence as well, since it will go on and on with these two, then what will you do?" 41 It is certainly true that such conceptualizations (kun rtog), [made] in the way an elephant bathes [in the mud], arise in those who, in reliance upon consciousness ( $\mathrm{rnam}$ shes, vijñana), take a point of view [based on] the confined perception of dogmatic logicians (tshur mthong rtog ge'i dbang du byas pa). ${ }^{42}$ As the inconceivable nature of phenomena (chos nyid, dharmatā) is supreme among [all kinds of] greatness that frighten the unfortunates, they do not understand its nature. When something is taught as the insubstantiality [of phenomena], they apprehend [it] as a nihilistic emptiness. When something is taught as that which is endowed with appearance, they apprehend it as really established. When something is termed "the unity [of appearance and emptiness]," they apprehend it as an object such as a rope [made of] of black and white braided strands. When something is termed "inconceivable," nothing dawns on them, aside from something like the Hwa shang's view of [mental] blankness. If everyone could easily understand this supreme and profound nature of phenomena (chos nyid, dharmatā), why is it said, ${ }^{43}$ "Being completely beyond the world, the sphere of the sublime ones is difficult to perceive and difficult to understand, inconceivable"? ${ }^{44}$

41 This represents the position of those for whom the principle of the excluded middle is valid (namely the dGe lugs pa), also on the level of the ultimate. The very negation of nonexistence establishes existence and vice versa. Hence the vicious circle mentioned here by the opponent's objection.

42 Cf. Arguillère, L'Opalescent Joyau Nor-bu ke-ta-ka. Mi pham (Paris: Fayard, 2004), 88, n. 2: "L'éléphant en se vautrant dans la boue se souille tout en se lavant. De même la notion de vacuité, en tant que telle, n'est-elle pas une idée fictive au même titre que les conceptions implicites du substantialisme naif ou les constructions savantes du substantialisme philosophique?"

43 I could not identify the source of this quote: de dag 'jig rten mtha' dag las 'das shing 'phags pa'i spyod yul blta dka' zhing shes par dka' bsam gyis mi khyab.

44 Nor bu ke ta ka, 27, 1ff.: re zhig thog med nas goms pa'i dngos po yod pa nyid du zhen pa de'i ngor byas nas med pa nyid du sgrub cing goms par byed de/ dngos po rang bzhin med par ma shes na gnas lugs mtha' bral la nges pa skye ba'i skabs gtan med pas so//'on kyang med pa nyid de tsam kho na gnas lugs mthar thug ni ma yin te/ gang tshe gzugs sogs dngos po gang zhig med do zhes brtag bya'i dngos po de tha snyad du rang gi ngo bos skye ba sogs su mi dmigs na/ de tshe de la rten pa'i dngos med kyang rten dngos po dang bral bas na/ blo yi mdun na dmigs gtad kyi yul du ji ltar gnas te gnas mi srid de mog sham gyi bu skye ba med na de shi ba'ang mi dmigs pa bzhin no/ des na med pa ni yod pa la brten nas bzhag pa tsam ltos med du ngo bos grub pa ni med do/'on yod pa bkag nas med pa sgrub/slar yang med pa'ang bkag nas yod pa sgrub/ de gnyis res mos spel bas ci zhig bya zer na/ mam shes la rton cing tshur mthong rtog ge'i dbang du byas pa dag la glang chen gyi khrus dang 'dra ba'i kun rtog 'di lta bu 'byung ba ni shin 
Equipped with this approach of the twofold ultimate corresponding to two different perspectives, Mipham aims at conciliating views ranging from those of the rDzogs chen to the dGe lugs pa tradition, as well as the classical Indian Svātantrika and Mādhyamika interpretations. With this uniquely inclusivist attitude within Tibetan Buddhism, Mipham attempts to make thirteen centuries of Buddhist Indo-Tibetan philosophical developments compatible with the highest teaching of his tradition, rDzogs chen. By stressing that the actual ultimate beyond all views is truly the nonconceptual ultimate, he echoes the rDzogs chen essential teaching distinguishing between sems and rig $p a$ in a move confirming rDzogs chen as the epitome of Buddhist views to protect it from sectarian attacks. Yet, as far as the nominal ultimate is concerned, Mipham accepts a position similar to that of the Svātantrikas and the dGe lugs pas for the sake of teaching beings on the path. In this respect, he goes as far as to provisionally accept Phya pa chos kyi seng ge's (1109-1169) position: The two truths can be said to be a single entity with different conceptual aspects (ldog pa tha dad pa'i ngo bo gcig), a position also held by Tsong kha pa and that Klong chen pa had expressly rejected in his Grub mtha' mdzod. ${ }^{45}$ In spite of this concession, Mipham unquestionably follows Go rams pa in his exposition of the two ultimates ${ }^{46}$ : on the level of the actual ultimate, the two truths are accepted to be in a state of unity (zung 'jug), being indivisible (dbyer med). In Mipham's systematic integration of ascending perspectives on reality into a coherent vision, the propaedeutic function of the view is therefore a soteriological necessity as his approach clearly aims at providing beginners on the spiritual path with a ladder linking both

tu bden te bsam gyis mi khyab pa’i chos nyid ni skal dman rnams skrag pa’i gnas che ba’i rab yin pas de'i tshul ni mi shes shing/ dngos med du bstan na chad stong du bzung/ snang bcas su bstan na bden grub tu bzung/ zung 'jug ces brjod na tha gu dkar nag bsgrel ba lta bu'i don du bzung/ bsam gyis mi khyab ces brjod na cang med ci med hwa shang gi lta ba lta bu zhig las mi 'char yin te/ zab mo'i mthar thug pa'i chos 'di kun gyis bde blag tu shes nus na/ de dag 'jig rten mtha' dag las 'das shing 'phags pa'i spyod yul blta dka' zhing shes par dka' bsam gyis mi khyab zhes ji ste gsung/

45 See Helmut Tauscher, "Phya pa Chos kyi Sen ge as a Svātantrika," in The Svātantrika-Pr āsañgika Distinction, ed. Georges B. J. Dreyfus and Sara L. McClintock (Boston: Wisdom, 2003), 235: "Phya pa lays great emphasis on determining the two truths as 'identical in nature and different with regard to the characteristic distinction' (ngo bo gcig la ldog pa tha dad pa). Equally, in Tson kha pa's Madhyamaka exegesis the same determination is of utmost importance, as it provides a basis for his interpretation of 'neither existent nor nonexistent' as meaning 'neither existent in an absolute sense nor nonexistent conventionally,' which is understood as referring to both truths and thus represents the essence of his ontology." On Klong chen pa's view, see Butters, "The Doxographical Genius of Klong chen rab 'byams pa," (PhD diss., Columbia University, 2006), 398, 411.

46 See Cabezón and Dargyay, Freedom from Extremes, 211-17. 


\section{the view and the practice of emptiness of lower approaches with that of higher ones: ${ }^{47}$}

The single entity corresponding to the single entity possessing different conceptual distinguishers (ldog pa tha dad pa'i ngo bo) of the two truths is the single entity of the indivisibility of appearance and emptiness (snang stong dbyer med). This is established through the valid modality of cognition that analyzes the two truths. Whatever appears is empty. If this emptiness existed as something different from appearance, since the essence of this phenomenon would become nonempty, these two would not be different. This entity, established as an indivisible entity, is the actual ultimate. This cannot be described as anything at all and is the sphere of direct knowledge or experience (so sor rang rig). This is dharmadhātu, the lineage (rigs, gotra) [of the buddhas], and so forth. Although it is the highest mode of being of all phenomena, it is not conceptualized. If it were not so, it would be a phenomenal appearance ( $m$ tshan ma, nimitta). From the perspective of the emptiness of the nominal ultimate, when the four extremes are refuted, the extreme of existence must be refuted by the nonexistence of [something] real, while the extreme of nonexistence [must be refuted] by conventional existence. Thus, from the perspective of the nature of things itself, the four extremes cannot be eliminated. The mode of being that is a mere negation (med dgag, prasajyapratisedha) has the potency to eliminate the extreme of affirming real existence. ${ }^{48}$ However, since the elimination of nonexistence depends on the concealing [truth], the mode of being itself, from its own perspective, would fall into the extreme [of nonexistence]. Therefore, this emptiness that represents a fall into the extreme [of nonexistence] is not the nature of phenomena (chos nyid, dharmatā $)^{49}$

47 This is also confirmed by Mipham in his 'Od gsal snying po; see Dharmachakra Translation Committee (trans.), Luminous Essence, A Guide to the Guhyagarbha Tantra, Jamgön Mipham (Boston: SLp, 2009), 65.

48 I would like to thank Professor Matthew Kapstein for his suggestions regarding the translation of this sentence.

49 'Jug 'grel, 576, 5ff.: bden gnyis ngo bo gcig la ldog pa tha dad pa'i ngo bo gcig pa de/ snang stong dbyer med ngo bo gcig yin la/ de ni bden gnyis dpyod pa’i tshad mas grub ste/ gang snang 'di stong/ stong pa de snang ba las tha dad du yod na/ chos de'i ngo bo mi stong bar 'gyur bas de gnyis tha dad du med do/ ngo bo dbyer med med par grub pa'i ngo bo de ni rnam grangs min pa'i don dam ste/ de la gang du'ang brjod mi shes te so sor rang gi yul lo/ de ni dbyings dang rigs sogs yin te/ chos kun gyi gnas lugs mthar thug yin gyi/ rnam grangs pa ni min no/ de min rtags/ mam grangs pa'i stong pa'i dbang du byas na/ mtha' bzhi 'gog tshe/ bden med kyi yod mtha' sel/ tha snyad du yod pas chad mtha' sel dgos la/ de ltar na gnas lugs rang gi ngos nas mtha' bzhi sel mi nus te/ gnas lugs med dgag la yod mtha' sel ba'i nus pa yod kyi/ med mtha' sel ba kun rdzob la ltos pa'i phyir/ gnas lugs kho rang gi ngos nas mthar lhung ba can du 'gyur bas/ de 'dra'i mthar lhung gi stong nyid de chos nyid ma yin no/ 


\section{Mipham's Perspectivist Discourse on the Inexpressible Ultimate}

Perspectives play a central role in Mipham's discourse on the ineffable. On the one hand, some of his statements seem to indicate that the actual ultimate is a cognitive object for sublime beings:

Realizing that these two [truths] are in the real sense in a state of unity (zung 'jug) or fundamental sameness (mnyam pa nyid) is the supreme object of realization, the ultimate purpose..$^{50}$

These statements, made from the perspective of ordinary beings, present the ultimate as an object that is to be realized by sublime beings and, in this respect, is compatible with the dGe lugs pa position:

With regard to this, insofar as all cognitive objects are distinguished on account of being correct or incorrect, they are completely included within the two truths. ${ }^{51}$

However, according to Mipham the ultimate, from the perspective of sublime beings, abides clearly beyond all designations:

In the absolute sense, the ground of emptiness

And that which is empty do not exist as being different.

The indivisibility of appearance and emptiness is inexpressible,

You must realize it directly for yourself! ${ }^{52}$

In his Nor bu ke ta ka, Mipham comments on Sāntideva's famous pādas (BCA $2 \mathrm{c}-\mathrm{d}$ ) on the impossibility of conceiving the ultimate. ${ }^{53}$ Various conflicting interpretations of these verses have triggered fierce debates and polemics in Tibet. ${ }^{54}$ About this fine point, Mipham declares in his Nor bu ke ta ka:

Moreover, it is also stated in the Madhyamakālaṃkära:

In the real sense, [the ultimate] is free from all accumulations of mental proliferations. [MA 70cd]

[Nonexistence,] being also based on conceptuality, is concealing [and] not genuine. [MA 72cd]

50 Mkhas pa'i tshul la 'jug pa’i sgo, 2:174: de gnyis yang dag pa’i don du zung 'jug mnyam pa nyid du rtogs pa ni rtogs bya rnams kyi nang na mchog tu gyur pa mthar thug gi don no/

$51 \mathrm{dBu}$ ma rgyan gyi rnam bshad, 18.2: de la shes bya 'di dag yang dag pa yin min gnyis kyis phye bas na bden pa gnyis su zad par'du zhing/

52 Shes rab ral gri, 799, 2ff.: /gnas lugs don la stong gzhi dang//stong pa tha dad du med pas// snang stong dbyer med brjod dang bral//so so rang gis rig bya'o/

53 See Vaidya, Bodhicaryāvatāra of Śāntideva, 170, line 27: buddher agocaras tattvam buddhị samvrtir ucyate//

54 See Viehbeck, Polemics in Indo-Tibetan Scholasticism. 
Hence it is explained here that the nature of phenomena (chos nyid, dharmatā) is not an object of cognition: inasmuch as the nature of phenomena is beyond all mental proliferations, it does not exist as an objective support for the intellect. As a consequence, how could we correctly call "cognitive object" that which is neither subject/object, nor established as any phenomenal appearance (mtshan ma, nimitta) at all ${ }^{55}$

In his commentary on Candrakīrti'Mādhyamakāvatāra XI, 12-13, Mipham explains, in agreement with the root text, that distinctions between objects and subjects are simply made for the sake of communication, namely, from the perspective of ordinary beings. Ultimately, subject and object are of a single essence. The core of the problem here is that since the ultimate is beyond the dichotomy of subject/object, it cannot be an object, or else it amounts to nothing but a thought:

The entity possessing an objective support (dmigs pa, àlambana),

Is a thought, which is the nature (rang bzhin) of the grasped object and the grasping subject. $^{56}$

Whatever is taken by this [thought] as a pseudo-objective support is falsehood

[Because this thought] does not actually come into contact with the nature of phenomena (chos nyid, dharmatā).

It is said in the sütras that

Taking the objective support to be something substantial or insubstantial,

Taking the objective support to be something dual or nondual,

No matter how one takes [something] as an objective support,

Whatever is grasped through this approach belongs to the domain of the demon

(bdud, māra) ${ }^{57}$

No refutation or proof at all

Can destroy what is taken as an objective support.

When one understands without eliminating or adding [anything], [this is] freedom. ${ }^{58}$

55 Nor bu ke ta ka, 8, 3ff.: rgyan las kyang/ yang dag tu spros pa yi/ tshogs rnams kun las de grol yin//rnam par rtog la brten na yang//kun rdzob tu 'gyur yang dag min//zhes so//de la 'dir chos nyid shes bya min par brjod pa ni/ chos nyid spros pa thams cad las 'das pas na/ de ni blos dmigs par byar med pas yin te/ gang yul dang yul can du ma gyur cing mtshan gang du'ang ma grub pa de la yang dag par na ji ltar shes bya zhes brjod de/

56 The subject/object division refers to duality.

57 Cf. Nāgārjuna, YṢ 36ab in Cristina A. Scherrer-Schaub, Yuktișașțikāvṛtti. Mélanges Chinois et Boudhiques, vol. 25 (Bruxelles: Institut Belge des Hautes Études Chinoises, 1991), 264: “Aussi grande est l'agitation de l'esprit, aussi étendu est le domaine de Māra."

58 Shes rab ral gri, 811, 3ff.: /dmigs pa can gyi bdag nyid ni//bzung dang 'dzin pa'i rang bzhin sems//de des gang dmigs de ltar rdzun//chos nyid don la dngos mi reg//dngos por dmigs dang dngos med dmigs//gnyis su dmigs dang gnyis min dmigs//ji ltar dmigs dang kyang dmigs pa ste//dmigs pas gang bzung bdud kyi ni//spyod yul yin zhes mdo las gsungs//dgag dang sgrub pa gang gis kyang//dmigs pa ’jig par mi nus la//bsal bzhag med par mthong na grol/ 


\section{The Two Truths from the Perspective of the Actual Ultimate}

Although Dreyfus seems to think that according to Mipham the actual ultimate is accessible to thought, there is a rather long explanation in his mKhas pa'i tshul la 'jug pa'i sgo presenting the ultimate as being beyond all extremes as the indivisibility of the two truths - that is, as the unique truth. ${ }^{59}$ This passage shows Mipham's willingness to facilitate the understanding of the ultimate based on conceptuality, but it also shows his reluctance to conflate the nominal ultimate with the actual, which remains beyond the sphere of thought:

Depending on the individual's intellectual capacity or acumen, emptiness exists as these two kinds of ultimate or emptiness: the nominal and the actual. The first, being the mere negation (med dgag, prasajyapratisedha) that all phenomena (chos, dharma) are established as truly [existent], is the object of a mode of perception ('dzin stangs), which has partially eliminated mental proliferations (spros pa, prapañca). It is not the realization of that which is completely free from mental proliferations. Inasmuch as this is merely an imputation with regard to the ultimate and emptiness, since it depends also on the nonexistence of substantial things, one must [still] understand the authentic ultimate, emptiness. Therefore, this [nominal ultimate] is called the concordant ultimate (mthun pa'i don dam). Further, the knowable phenomena that are the objects of an intellect endowed with conceptuality (rnam par rtog pa, vikalpa) are only posited as existent by means of dependent arising and dependent imputation. [265] The conditioned [phenomena] produced from causes and conditions exist on account of dependent arising. Although unconditioned [phenomena] do not arise out of causes, they exist by means of dependent

59 See Georges B. J. Dreyfus, "Would the True Prāsangika Please Stand? The Case and View of 'Ju Mi pham," in The Svātantrika-Prāsañgika Distinction, ed. Georges B. J. Dreyfus and Sara L. McClintock (Boston: Wisdom, 2003), 335: "Go rams pa holds that this is the case, that the actual ultimate is not accessible to thought and is thus utterly ineffable. Mi pham disagrees, arguing that if this were so, ordinary beings would never understand such an ultimate since they could never develop the causes that lead to the generation of primordial wisdom. Thus, for Mi pham, the actual ultimate is accessible to thought, even though its access is different from that of wisdom. Whereas the latter realizes the ultimate by refuting all four extremes simultaneously, thought proceeds in succession.” It seems to me that Dreyfus does not consider the fact that, according to Mipham as well, as long as extremes and dualistic thoughts are involved, the actual ultimate is not attained. Mipham's quotes above make it clear that the actual ultimate is beyond all extremes. Therefore, a mere intellectual gradual process of negation of the four extremes cannot, according to Mipham, involve the actual ultimate. Arguillèr, L'Opalescent Joyau Nor-bu ke-ta-ka, 57, n. 1 concurs: "Dans la doctrine de Mi pham, quand on dit que l'absolu n'est pas perçu par la connaissance principielle elle-même, ce n'est pas au sens où elle l'ignorerait, mais au sens où il ne saurait être un objet dont elle serait le sujet cognitif. Il s'agit d'une connaissance immédiate, tellement étrangère aux formes de connaissance qui nous sont familières que l'on peut aussi bien parler d'inconnaissance." 
imputation. They and their conventional designations (tha snyad) are established insofar as each of them eliminates its own antithesis (dgag bya), like space with regard to obstructive physical contact (thogs re), like the cessation [acquired by] discernment (brtags 'gog, pratisamphyānirodha) in the case of the exhaustion of what is to be abandoned, like the cessation [acquired by] nondiscernment (brtags min 'gog, apratisamkhyānirodha) in the case of what is nonarisen anywhere, or like the definition of nonexistence [which is established] in relation to the elimination of real existence.

On account of this, since unconditioned [phenomena] also are not beyond the dependent arising of dependent imputation, it is said [MMK 24.19ab]: ${ }^{60}$

No phenomenon is existent

That does not arise in dependence.

Since such unconditioned [phenomena] are unconditioned and without any substantiality, being only imputations projected by the intellect (blos phar brtags) and objects knowable only by conceptuality, they are not the inconceivable nature of phenomena (chos nyid, dharmatā). For this reason, when they are examined by the intellect, as not a single one of them is not empty of an own-nature, they are ultimately nonexistent as [anything] observable. It is said [MMK $24.19 \mathrm{~cd}]:^{61}$

Therefore, no phenomenon exists

That is not emptiness.

Likewise, there is not a single phenomenon, substantial or insubstantial, that is not empty of own-nature. However, the incontrovertible appearances of conventional designations manifest although they have been empty from the beginning. As a consequence, the realization that appearance and emptiness free from contradiction are equivalent is thus expressed by the following statement [Vigrahavyāvartanìvrtti on Vigrahavyā vartanī 70] ${ }^{62}$ :

Being empty of anything and being dependently originated Are equivalent according to the Way of the Middle.

Such is the supreme teaching.

60 apratītya samutpanno dharmah kaścin na vidyate |; see L. de La Vallée Poussin, Mūlamadhyamakakārikās (Mādhyamikasūtras) de Nāgārjuna avec la Prasannapadā Commentaire de Candrakirti (St. Petersburg: Imprimerie de l'Académie Impériale des Sciences, 1913). D3824, f.15a: /de phyir stong pa ma yin pa'i//chos 'ga' yod pa ma yin no/

61 yasmāt tasmād aśūnyo hi dharmạ̣ kaścin na vidyate ॥; see La Vallée Poussin, Mūlamadhyamakakārikās. D3824, f.15a: /de phyir stong pa ma yin pa'i//chos 'ga' yod pa ma yin no/ 62 bhavati cātra yah śūnyatām pratītyasamutpādam madhyamām pratipadam ca | ekārthām nijagāda; see E. H. Johnston and A. Kunst, "Vigrahavyāvartanī," in The Dialectical Method of Nāgārjuna, ed. Bhațacharya (Delhi: Motilal Banarsidass, 1978). D3828, f.29a: /de la ci yang mi srid do/ /gang zhig stong dang rten 'byung dag /dbu ma’i lam du don gcig par//gsung mchog mtshungs pa med pa. 
In their real condition, all imputations in terms of substantial (dngos) and insubstantial things (dngos med) are bereft of [any] fixation grasping [them] as being distinctly different. That which abides in the nature free from all mental proliferations, the nature of phenomena (chos nyid, dharmatā), which is the undifferentiation of dependent arising and emptiness or appearance and emptiness, must be realized by gnosis, intuitive knowing, without conceptualizing what is free from subject and object. This realization is the actual ultimate.

This [actual ultimate] is designated by means of various synonyms, such as the ultimate truth, the limit of reality (yang dag pa'i mtha'), or true reality. It is not merely mentally imputed. The utterly natural (rang bzhin bab) mode of being of all phenomena is primordially present, unchanging throughout the three times, and beyond the sphere of conceptuality (rnam par rtog pa) or mental imputations. Since all phenomena are fundamental sameness in their [original] condition, there is no other phenomenon at all apart from dharmadhātu. This emptiness endowed with the supreme excellence of all aspects (rnam pa kun gyi mchog) is the unexcelled ultimate among all kinds of realization of the Great Vehicle.

This unconditioned unity [of appearance and emptiness] is unlike an unconditioned insubstantial thing (dngos med). It is the great unconditioned that does not abide in the extremes of that which is a substantial or an insubstantial thing. Not only is this [unconditioned unity] not merely arisen owing to causes, but it is [in fact] the real unconditioned since it is moreover beyond the conventions corresponding to the perceptions of what is merely established by imputations made in dependence (ltos nas btags pa). Considering this [real unconditioned], the learned (ācārya) Nāgārjuna thus declared [in MMK 25.13cd]: ${ }^{63}$

Substantial things and insubstantial things are conditioned,

Nirvāna is unconditioned. [267]

and [in $M M K$ 18.7]: ${ }^{64}$

Objects of designation have ceased (ldog $p a)$,

Since the sphere of mind's objects has ceased.

Unborn and unceasing,

The nature of phenomena (chos nyid, dharmatā) is equal to nirvāna.

The Dharmarāja Kulika Mañjuśrīkīrti said ${ }^{65}$ :

The aggregates, [when] examined, are emptiness,

Devoid of an essence like the plantain tree.

This is not like the emptiness

That is endowed with the supreme excellence of all aspects.

63 asaṃskṛtaṃ hi nirvāṇaṃ bhāvābhāvau ca saṃskṛtau || D3824, f.16b: /mya ngan 'das pa 'dus ma byas/ / dngos dang dngos med 'dus byas yin/. Pādas c and d are inverted in Mipham's quotation.

64 nivrttam abhidhātavyam niṿ̛ttaś cittagocarah | anutpannāniruddhā hi nirvāṇam iva dharmatā || D3824, f.11a: /brjod par bya ba ldog pa ste//sems kyi spyod yul ldog pas so//ma skyes pa dang ma 'gags pa/ /chos nyid mya ngan 'das dang mtshungs/

65 Pradarśanānumatoddeśaparīkșā (T2609); see Rolf Scheuermann, "Das gZhan stong dbu ma’i rgyan des rJe btsun Tāranātha Kun dga' snying po Tibetischer Text und Übersetzung” (PhD diss., University of Vienna, 2010), 43, 78. 
Thus, there is no differentiation into two distinct truths from the perspective of those who have realized [this]. It is realized that all phenomena are equivalent to dharmadhātu, fundamental sameness, the single sphere (thig le nyag gcig), or the center of the vajra space. Therefore, it is said [in RGV I.154, AA V, 21, and elsewhere] ${ }^{66}$ :

There is nothing to eliminate from this,

Not even the slightest thing to add.

The truth should be perceived as it is.

The one who perceives the truth is liberated. ${ }^{67}$

As stated here, you will have reached the heart of the subject of all that is explained in Mahāyāna as fundamental sameness free from mental proliferations. Now, one may think, "[In this case,] the distinction in terms of the two truths makes no sense! There is only one truth.” The distinction into two truths makes sense because it is the method introducing this single truth, the ultimate truth, the final limit (mthar thug pa), dharmadhātu, or fundamental sameness. [268] The Conqueror declared that the single absolute truth is the unborn nirvāna, all phenomena being primordially pacified, namely fundamentally the same (mnyam pa). The great charioteers have established [this] accordingly in [their] treatises (bstan bcos, śāstra) ${ }^{68}$

66 See Jikidō Takasaki, A Study on the Ratnagotravibhāga (Uttaratantra): Being a Treatise on the Tathāgatagarbha Theory of Mahāyāna Buddhism (Rome: Istituto italiano per il Medio ed Estremo Oriente, 1966), 300.

67 nāpaneyam atah kị̣cid upaneyaṃ na kimcana / drașțavyạ̣ bhūtato bhūtam bhūtadarś̄i vimucyate. (See Johnston, Ratnagotravibhāga). D4024, f.61b: /'di la bsal bya ci yang med//gzhag par bya ba cung zad med/ /yang dag nyid la yang dag lta//yang dag mthong na rnam par grol/ 68 Mkhas pa'i tshul la 'jug pa'i sgo, 3:264ff.: stong nyid de la gang zag gi blo 'jug pa'i rim pa'am/ rtogs tshul gyi dbang du byas na/ rnam grangs dang/ rnam grangs min pa'i don dam mam stong nyid gnyis su yod de/ dang po chos kun la bden grub tsam khegs pa'i med dgag ste/ spros pa phyogs re bcad pa'i 'dzin stangs kyi yul spros bral mtha' dag ma rtogs pa'o// 'di ni don dam pa dang stong pa nyid btags pa tsam las/dngos min yang 'di la bten nas don dam stong pa nyid mtshan nyid pa rtogs dgos pas mthun pa'i don dam zhes bya'o// de la rnam par rtog pa dang bcas pa'i blo'i yul du gyur pa'i shes bya'i chos 'di mams brten nas skye ba dang/ brten nas btags pa gnyis kyi sgo nas yod par bzhag pa kho na yin te/ rgyu rkyen las skyes pa'dus byas mams ni/ brten nas skye ba'i sgo nas yod pa'o/ 'du ma byas rnams rgyu las skyes pa min yang/ brten nas btags pa tsam gyi sgo nas yod pa ste/ de dag rang rang gis dgag bya rnam par bcad pa las de dang de'i tha snyad 'grub pa/ thogs reg med pa la nam mkha' dang/ spang bya zad pa la brtags 'gog dang/ gang na gang ma skyes pa la brtags min 'gog pa dang/ bden grub bsal ba'i cha nas bden med du 'jog pa bzhin no// de'i phyir 'dus ma byas rnams kyang brten nas btags pa'i rten 'byung las ma 'das pas na/ rten cing 'brel 'byung ma yin pa'i//chos 'ga' yod pa ma yin no// zhes gzungs la/ 'di 'dra'i 'dus ma byas 'di dag ni dngos med 'dus ma byas yin pas rnam rtog kho nas shes par bya ba'i yul dang/ blos phar btags pa tsam ste chos nyid bsam gyis mi khyab pa ma yin no// de'i phyir 'di dag la blos gzhig na rang gi ngo bos mi stong pa gang yang med pas don dam par dmigs su med pa yin pas/ de phyir stong nyid ma yin pa'i/ chos 'ga' yod pa ma yin no/ zhes gsungs so// de ltar dngos dngos med kyi chos mtha' dag rang gi ngo bos mi stong pa med kyang/ tha snyad kyi snang ba bslu ba med pa rnams ye nas stong bzhin du snang ba yin 


\section{Conclusion}

Mipham's inclusivist exposition of the relationship between the two truths is thus clearly based on a set of ascending perspectives as explained in the following passage of the Nges shes sgron me:

Whatever appears is pervaded by emptiness,

And whatever is empty is pervaded by appearance,

Since if something appears, it cannot be nonempty

And this emptiness is not established as something that does not appear.

Moreover, since both a substantial thing and an insubstantial thing,

Taken as the bases of emptiness, must be empty,

All appearances are nothing but something imputed

pas snang stong 'gal med don gcig tu rtogs pa ni/ gang gis stong dang rten 'byung dag// dbu ma'i lam du don gcig par//gsung mchog zhes gzungs pa ltar/ gang dngos dngos med du btags pa rnams kyang yang dag pa'i don du so sor rang sa na ma 'dres par tha dad pa'i tshul du 'dzin pa'i zhen pa dang bral te/ snang dang stong pa'am stong dang rten 'byung tha mi dad pa'i chos nyid spros pa mtha' dag dang bral ba'i rang bzhin du gnas pa gang zhig gzung 'dzin med pa rnam par mi rtog pa'i ye shes so rang rig pas rtogs par bya ba ni rnam grangs min pa'i don dam yin te/ 'di la ni chos kyi dbyings dang/ don dam pa'i bden pa dang/ yang dag pa'i mtha' dang/ de bzhin nyid la sogs pa'i rnam grangs sna tshogs su gdags par mdzad do// 'di ni blos btags pa tsam ma yin te/ chos thams cad kyi rang bzhin bab kyi gnas lugs ye nas gnas shing dus gsum gyi 'gyur ba med pa/ blos btags dang rnam par rtog pa'i yul las 'das pa/ de'i ngang du chos thams cad mnyam pa nyid du gyur pas chos kyi dbyings las ma gtogs pa'i chos gzhan ci yang med pa rnam pa kun gyi mchog dang ldan pa'i stong pa nyid 'di ni theg pa chen po'i rtogs rigs thams cad kyi nang na bla med pa'i mthar thug pa'o// zung 'jug 'dus ma byas pa 'di ni dngos med 'dus ma byas dang mi 'dra zhing dngos dngos med gang gi mtha' la'ang mi gnas pa'i 'dus ma byas chen po yin te/ 'di rgyas ma bskyed pa tsam du ma zad/ltos nas btags pas grub pa tsam kyis dmigs pa'i tha snyad las kyang 'das pa'i phyir'dus ma byas yang dag yin pa de la dgongs nas mgon po klu sgrub kyi zhal snga nas/ dngos dang dngos med 'dus byas yin/ mya ngan 'das pa 'dus ma byas//zhes dang/ brjod par bya ba ldog pa ste/ sems kyi spyod yul ldog pas so/ ma skyes pa dang ma 'gags pa/ /chos nyid mya ngan 'das dang mtshungs//zhes sogs gsungs shing/ chos kyi rgyal po rigs ldan 'jam dpal grags pa'i zhal snga nas/ phung po rnam dpyad stong pa nyid/ chu shing bzhin du snying po med/ mam pa kun gyi mchog ldan pa'i/ stong nyid de dang 'dra ma yin/ zhes gsungs pa'i don no// de ltar rtogs pa'i ngor bden pa gnyis su tha dad du phye ba med de chos thams cad chos kyi dbyings mnam pa nyid thig le nyag gcig rdo rje nam mkha'i dkyil lta bur rtogs pas na/'di la bsal bya ci yang med/ bzhag par bya ba cung zad med/yang dag nyid la yang dag lta/yang dag mthong nas rnam par grol/zhes gsungs pa ltar/ theg pa chen po na spros bral mnyam pa nyid du gsungs pa thams cad kyi don gting sleb par 'gyur ro // 'o na bden pa gnyis su phye ba don med cing bden pa gcig tu 'gyur ro snyam na/ bden pa gnyis su phye ba ni bden pa gcig pu don dam bden pa mthar thug pa chos dbyings mnyam pa nyid 'di la 'jug pa'i thabs yin pas don yod la/ mthar thug pa bden pa gcig pu chos thams cad gdod nas zhi zhing ma skyes la mya ngan las 'das pa mnyam pa nyid yin par rgyal ba nyid kyis gsungs shing/ shing rta chen po rnams kyis bstan bcos dag las kyang de ltar bsgrubs zin to// 
And even emptiness is merely imputed by the intellect.

With respect to the knowledge that is ascertained through rational analysis, These two are the method and the result of the method.

Inasmuch as, if there is one, not having the other

Is impossible, they abide inseparably.

Therefore, also when appearance and emptiness

Are known individually,

In fact, they are never divisible.

Therefore, since the certainty that perceives the nature of things

Does not fall into any extreme,

They are said to be in unity (zung 'jug).

From the perspective of the insight which correctly analyzes, [97]

These two, appearance and emptiness,

Are considered to be a single entity with different conceptual aspects (ngo bo gcig ldog pa

tha dad),

As they exist or do not exist jointly.

Moreover, for beginners,

They appear as negandum and negation.

At that time, they are not mingled as a single [entity].

One day, one attains the certainty

That the nature of emptiness arises as appearance.

Inasmuch as that which is primordially empty and appearances are both empty,

This is the birth of the certainty that perceives

Appearances, although they are empty,

And emptiness, although it manifests as appearances.

This is the root of all profound paths

Of sūtra, tantra, and pith instructions.

This point, which cuts off superimpositions

With regard to study and reflection,

Is the correct, undeluded view. ${ }^{69}$

69 Pettit understands this sentence differently:

"This is the meaning of cutting off misconceptions

Through study and reflection;

It is the unmistaken, authentic view" (Pettit, Mi pham's Beacon of Certainty, 216).

Since a direct criticism of a merely intellectual understanding of emptiness follows, I understand sgro 'dog chod pa'i don as the elimination of superimpositions related to study and reflection; this is based on the different contexts in which this term is used, such as:

Shes rab ral gri, 800.3ff.:

"[The other one,] the vast cognition

Arising from the contemplation of the nature of phenomena, as it is,

Eliminating the superimpositions (sgro 'dogs) with regard to the inconceivable object,

Is endowed with the fruit of the knowledge of all there is."

Nor bu ke ta ka, 6, 2: "Therefore, as long as this dharmadhātu that is the union of experience and emptiness, free from the thirty-two superimpositions, is not made manifest, the perfection of insight is not authentic." 
By realizing this key point more and more profoundly, The clinging to the characters

Of the appearances of the concealing truth as well

Will be abandoned.

Therefore, according to the progression of the tantric vehicles, The appearances that are nothing but intellectual wishful thinking

And the appearances of the world and its beings as deities

That are the confidence in the view [arising] from certainty

Cannot possibly be the same. ${ }^{70}$

Determining through Madhyamaka

That phenomena (chos, dharma) are devoid of truth is a view.

When a Brahmin recites mantras for a sick person,

His wishful thinking that there is [in fact] no disease is not the view.

By realizing the ultimate nature of things,

The certainty that the concealing truth is the deity [will be attained].

Otherwise, grounded in the level of deceptive appearances,

How can one accomplish the deity?

Apart from the deceptive appearance of an apprehending subject and an apprehended object,

That which is called samsāra does not exist.

The divisions of the path that bring an end to it,

Are not [made] from the perspective of the ultimate truth,

Since the ultimate, as it is, is oneness. ${ }^{71}$

70 Pettit understands this in a slightly different way:

"Intellectual wishful thinking and

The view of certainty that finds confidence in the

Divine experience of animate and inanimate phenomena

Cannot possibly be the same" (Pettit, Mi pham's Beacon of Certainty, 217).

71 Nges shes sgron me, 96, 3ff.: gang snang stong pas khyab pa dang//gang stong snang bas khyab pa ste//snang na mi stong mi srid cing//stong de'ang ma snang mi grub phyir//dngos dang dngos med gnyis po yang//stong gzhir byas nas stong dgos phyir//snang kun btags pa tsam zhig la//stong pa'ang blo yis btags pa tsam//rig pas dpyad pas nges shes la//'di gnyis thabs dang thabs byung ste//gcig yod na ni gcig med pa//mi srid pa du 'bral med par gnas//de phyir snang dang stong pa dag//so so'i char ni shes na yang//don du nam yang dbye ba med// de phyir zung 'jug ces brjod do/ /gnas lugs mthong ba'i nges shes ni//gang mthar lhung ba med phyir ro/ /yang dag dpyod pa'i shes [97] rab ngor//snang dang stong pa 'di gnyis po/ /yod mnyam med mnyam ngo bo gcig//ldog pa tha dad dbye bar 'dod//de yang dang po'i las can la/ /dgag bya 'gog byed lta bur snang//de tshe gcig tu 'dres pa med//nam zhig stong pa'i rang bzhin/ /snang bar 'char la yid ches thob//de yang gdod nas stong pa dang//snang ba 'di dag stong pa yis/ /stong bzhin snang la snang bzhin du/ /stong mthong nges shes skye ba nyid//'di ni mdo rgyud man ngag gi//lam zab kun gyi rtsa ba ste//thos bsam sgro 'dogs chod pa'i don/ / yang dag lta ba 'khrul med yin//gnad de je bas je zab tu//rtogs pas kun rdzob snang ba yang// rang mtshan zhen pa rim spong bas//rgyud sde'i theg rim de ltar snang//yid kyis mos bskom tsam zhig dang/ /snod bcud ltar snang nges shes kyis/ /lta ba gdengs su gyur pa gnyis/ / mtshungs pa'i go skabs mi srid da/ /dbu mas chos rnams bden stong du/ / nges ba gang de lta 
In the abovementioned quote from the Nges shes sgron me as well as in Mipham's other Madhyamaka works, we frequently find the interesting formulaic phrase ngos nas or ngor. To illustrate this point, the last sentence in the preceding quote thus reads: /don dam kho na'i ngos nas $\mathrm{min} /$, with the view to making explicit the standpoint from which a statement is made. This expression ngos nas/ngor is of considerable significance to understanding Mipham's presentation of the two truths. Mipham redefines the framework of valid cognitions based on the perspective of ordinary beings on the one hand, and sublime beings on the other. The expressions ngos nas and ngor are consistently used to determine from which perspective Mipham speaks. According to Mipham, some statements that are final from a deluded point of view are merely provisional from the perspective of sublime beings. For instance, views pertaining to the ultimate that are expressed in dualistic terms on the basis of affirmations and negations still miss the mark from a higher point of view. Mipham's presentation of the two truths thus hinges on the notion of perspectives, outlooks, and cognitive modes of apprehension of our so-called reality since, according to him, any discourse on this reality is in fine formulated from a specific epistemic viewpoint. From this perspective (pun intended!), charges of inconsistency become meaningless if Mipham's statements are adequately contextualized. With his perspectivist interpretation of Buddhist doctrines, Mipham teaches Madhyamaka through a series of ascending views, the aim of which is to provide beings with a gradual path in their spiritual journey toward the realization of the actual ultimate.

In Mipham's view, any discourse on the two truths necessarily takes place within the concealing truth and therefore only makes sense on account of its propaedeutic function in a given context. Mipham accordingly uses various models of the relationship between the two truths. These models correspond to various stages of the path or circumstances: (1) from the perspective of a beginner, the two truths can be seen as "different in the sense that their identity is negated" (gcig pa dkag pa'i tha dad or ngo bo gnyis); ${ }^{72}$ (2) from the perspective

yin la/ /bram ze'i nad la sngags 'debs cho/ / nad med mos pa lta min bzhin/ / don dam gnas lugs rtogs pa yis/ /kun rdzob lha ru yid ches kyi//gzhan du 'khrul pa'i snang tshul la/ /gnas nas lha ru ji ltar 'grub//gzung 'dzin 'khrul snang 'di min pa'i//'khor ba zhes bya gzhan du med//de spong lam gyi dbye ba rnams//don dam kho na’i ngos nas min//don dam [98] tshul gcig nyid yin phyir/

72 In the aforementioned quote from Nges shes sgron me, all of the various interpretations of the relationship between the two truths are listed. For an example of Mipham's use of gcig pa dkag pa'i tha dad, see his gZhan stong khas len seng ge'i nga ro in Pettit, Mi pham's Beacon of Certainty, 417, in which Mipham notes that the two truths are mutually exclusive in the gzhan stong approach. On ngo bo gnyis, see Phuntsho, Mi pham's Dialectics and the Debate of Emptiness, 151. 
of postmeditation, they are "different conceptual distinguishers with regard to a single entity" (ngo bo gcig la ldog pa tha dad); (3) from the perspective of meditative absorption, they are beyond extremes in an ineffable state of "unity" (zung 'jug), as explained by Mipham in his $d B u$ ma rgyan gyi rnam bshad: ${ }^{73}$

In short, the ultimate condition as the focus object of the meditative absorption that is beyond the sphere of conceptuality and language is indivisible within [two] truths. From this perspective, one need not distinguish the two truths. Therefore, as there is no assertion at all establishing or refuting that all phenomena appearing in this way exist or not, are this or not, and so forth, this [ultimate condition] is like answering by not saying anything. ${ }^{74}$ Since it is verily beyond conventional designations and since it is the inexpressible fundamental sameness free from mental proliferations, it is established as being without [any] assertion. However, from the perspective of postmeditation that is the sphere of words and conceptuality, namely, the mode of appearance [of phenomena], one reflects by oneself on the presentation of the ground, path, fruit, and so forth and when one then needs to speak for the benefit of others, as one distinguishes the two valid modalities of cognition, it is impossible not to engage in the procedure of refuting and establishing [phenomena]. ${ }^{75}$

In Mipham's approach, these three types of perspectives would respectively correspond to the view of: (1) beginners following any approach dichotomizing nirvāna, the unconditioned, and samsāra, the conditioned; (2) Svātantrika Madhyamaka; (3) Prāsañgika Madhyamaka. ${ }^{76}$ On account of their propaedeutic value, these three different approaches are used in different contexts: (1) to introduce beginners to the two truths; (2) to explain the nominal ultimate, and (3) to point at the actual ultimate.

To conclude, what appears contradictory on the level of a purely synchronic exposition of the two truths corresponds, in fact, to a diachronic unveiling of the nature of reality. This is why, for Mipham, an ascending scale of views aiming at

73 See Viehbeck, "Fighting for the Truth" for the contextualization of these perspectives in the polemics between Mipham and dGe lugs pa scholars.

74 This statement refers to the Buddha's silence and to the fact that one has no view from this specific standpoint.

75 dBu ma rgyan gyi rnam bshad, 29, 2ff.: mdor na mnyam gzhag sgra dang rtog pa’i yul las 'das pa'i gzhal don ltar mthar thug gi gnas tshul bden pa dbyer med kyi dbang du byas na ni bden gnyis phye mi dgos pas 'di ltar snang ba'i chos thams cad ye nas yod med yin min sogs dgag sgrub kyi khas len gang yang med pas ci'ang mi gsung ba'i tshul gyis lan btab pa dang 'dra bar yang dag par na tha snyad thams cad las 'das shing brjod du med pa dang spros pa dang bral ba dang mnyam pa nyid kyi phyir khas len med par grub kyang/ rjes thob sgra rtog gi yul du gyur pa snang tshul gyi dbang du byas te gzhi lam bras bu sogs kyi rnam gzhag zhig rang gis bsam zhing gzhan la'ang smra dgos na ni tshad ma gnyis phye ste dgag sgrub kyi tshul la 'jug pa las 'da' ba mi srid do/

76 See Duckworth, Mipam on Buddha Nature, 85. 
providing guidance to beings who are practicing this path has some merit, if this process of disclosure has to take place in a gradual way. From such a soteriological perspective, any presentation of these philosophical views by way of an exclusivist approach would therefore be absurd. On account of its pragmatic concern, Mipham's integrative approach could therefore be seen as a form of hierarchical soteriological inclusivism in which the validity of any discourse on the inexpressible reality is measured through its propaedeutic value in a given situation. In other words, views on the relationship between the two truths that are antidotes to delusion should not be evaluated independently of their soteriological efficacy with regard to their specific underlying cognitive or epistemic context. Paradoxically as it may sound, this does not, however, imply that these views should be seen as being necessarily equal. Since they are formulated from the perspective of an ascending scale of cognitive or epistemic contexts, they constitute a de facto hierarchy of possible discourses on reality.

\section{Bibliography}

\section{Tibetan Sources}

dBu ma rgyan gyi rnam bshad dBu ma rgyan gyi rnam bshad 'jam dbyangs bla ma dgyes pa'i zhal lung, Mi pham gsung 'bum. In W23468, Vol. 13, 1-416.

mKhas pa'i tshul la 'jug pa'i sgo mKhas pa'i tshul la 'jug pa'i sgo zhes bya ba'i bstan bcos bzhugs so. In Erik P. Kunsang, Gateway to Knowledge, Vol.I-III (Kathmandu: Rangjung Yeshe Publ., 1997-2002).

Nor bu ke ta ka sPyod 'jug shes rab kyi le'u'i tshig don go sla bar rnam par bshad pa Nor bu ke ta ka, Mi pham gsung 'bum. In W23468, Vol. 14, 1-96.

Ye shes snang ba Chos dang chos nyid rnam par 'byed pa'i tshig le'ur byas pa'i 'grel pa ye shes snang ba rnam 'byed, Rumtek. In Klaus-Dieter Mathes, Unterscheidung der Gegebenheiten von ihrem wahren Wesen (Dharmadharmatāvibhāga) (Swisttal-Odendorf: Indica et Tibetica Verlag, 1996) 297-307.

Shes rab ral gri Don rnam par nges pa shes rab ral gri, Mi pham gsung 'bum. In W23468, Vol. 4, 787-820.

'Jug 'grel dBu ma la 'jug pa'i 'grel ba zla ba'i zhal lung dri med shel 'phreng, Mi pham gsung 'bum. In W23468, Vol. 1, 497-816.

Mi pham gsung 'bum 'Jam mgon 'ju mi pham rgya mtsho'i gsung 'bum rgyas pa sde dgon chen par ma, Paro, sDe dge Par khang, 1984-1993 (W23468).

Nges shes sgron me Nges shes rin po che'i sgron me, Mi pham gsung 'bum. In W23468, Vol. 9, 71-123. 


\section{Academic Sources}

Arguillère, Stéphane. "Le Repos de l'esprit, la question de voie graduée dans le rDzogs pa Chen po selon quelques oeuvres de Klong chen Rab 'byams.” MA thesis, Paris, 1991. Arguillère, Stéphane. L'Opalescent Joyau Nor-bu ke-ta-ka. Mi pham. Paris: Fayard, 2004. Butters, Albion M. The Doxographical Genius of Klong chen rab 'byams pa. PhD diss., Columbia University, 2006.

Cabezón, José Ignacio, and Dargyay, Geshe Lobsang, trans. Freedom from Extremes, Gorampa's 'Distinguishing the View' and the Polemics of Emptiness. Boston: Wisdom, 2007.

de La Vallée Poussin, L. Mūlamadhyamakakārikās (Mādhyamikasūtras) de Nāgārjuna avec la Prasannapadā Commentaire de Candrakīrti. St. Petersburg: Imprimerie de l'Académie Impériale des Sciences, 1913.

Dharmachakra Translation Committee, trans. Luminous Essence, A Guide to the Guhyagarbha Tantra, Jamgön Mipham. Boston: SLp, 2009.

In The Svātantrika-Prāsañgika Distinction, edited by Georges B. J. Dreyfus and Sara L., 317-347. McClintock. Boston: Wisdom, 2003.

Duckworth, Douglas S. Mipam on Buddha Nature. Albany: State University of New York Press, 2008.

Duckworth, Douglas S. Jamgön Mipam: His Life and Teachings. Boston: Shambhala, 2011.

Goodman, Steven D. "Mi-pham rGya-mtsho: An Account of his Life, the Printing of his Works, and the Structure of his Treatise Entitled mkhas-pa'i tshul la 'jug pa'i sgo." In Wind Horse, edited by Ronald M. Davidson, 59-78. Fremont: Jain Publishing Company, 1981.

Hacker, Paul. "Inklusivismus." In Inklusivismus: Eine indische Denkform, edited by Gerhardt Oberhammer, 11-28. Vienna: Institut für Indologie der Universität Wien, 1983.

Higgins, David. The Philosophical Foundations of Classical rDzogs chen in Tibet: Investigating the Distinction between Dualistic Mind (sems) and Primordial Knowing (ye shes). Vienna: Wiener Studien zur Tibetologie und Buddhismuskunde, 2013.

Johnston, E. H. Ratnagotravibhāga Mahāyānottaratantraśāstra by Asañga. Patna: Bihar Research Society, 1950.

Johnston, E. H. and Kunst, A. "Vigrahavyāvartanī." In The Dialectical Method of Nāgārjuna, edited by Bhațțacharya, 42-86. Delhi: Motilal Banarsidass, 1978.

Kapstein, Matthew. “Mi-pham's Theory of Interpretation.” In Buddhist Hermeneutics, edited by Donald Lopez, 149-174. Honolulu: University of Hawai'i Press, 1988.

Kapstein, Matthew. "We are all gZhan stongs pas." Journal of Buddhist Ethics 7 (2000): 105-125.

Kapstein, Matthew. Reason's Traces. Boston: Wisdom, 2001.

Kawamura, Leslie S. “The Akșayamatinirdeśasūtra and Mi pham's mKhas'jug." In Contributions on Tibetan and Buddhist Religion and Philosophy, edited by Ernst Steinkellner and Helmut Tauscher, 131-145. Vienna: Wiener Studien zur Tibetologie und Buddhismuskunde, 1983.

Li, Xuezhu. “Madhyamakāvatāra-kārikā.” China Tibetology 1 (2012): 1-16.

Lipman, Kennard, and Norbu, Namkhai. Primordial Experience. Boston: Shambhala,1986.

Mathes, Klaus-Dieter. Unterscheidung der Gegebenheiten von ihrem wahren Wesen (Dharmadharmatāvibhāga). Swisttal-Odendorf: Indica et Tibetica Verlag, 1996.

Mimaki, Katsumi. Blo gsal grub mtha': Chapitres IX (Vaibhāṣika) et XI (Yogācāra) édités et Chapitre XII (Mādhyamika) édité et traduit. Kyoto: Zinbun Kagaku Kenkusyo, 1982. 
Pettit, John W. Mi pham's Beacon of Certainty: Illuminating the View of Dzogchen, the Great Perfection. Boston: Wisdom, 1999.

Phuntsho, Karma. Mi pham's Dialectics and the Debate of Emptiness. New York: Routledge Curzon, 2005.

Phuntsho, Karma. "'Ju Mi pham rNam rgyal rGya mTsho. His Position in the Tibetan Religious Hierarchy and a Synoptic Survey of his Contributions." In The Pandita and the Siddha, Tibetan Studies in Honour of E. Gene Smith, edited by Ramon N. Prats, 191-209. Dharamsala: Amnye Machen Institute, 2007.

Scherrer-Schaub, Cristina A. Yuktișașțikāvrttti. Mélanges Chinois et Boudhiques. Vol. 25. Bruxelles: Institut Belge des Hautes Études Chinoises, 1991.

Scheuermann, Rolf. Das gZhan stong dbu ma'i rgyan des rje btsun Tāranātha Kun dga' snying po Tibetischer Text und Übersetzung. PhD diss., University of Vienna, 2010.

Schuh, Dieter. Tibetische Handschriften und Blockdrucke sowie Tonbandaufnahmen tibetischer Erzählungen. Vol. 11.5. Wiesbaden: Franz Steiner Verlag, 1973.

Smith, E. Gene. Among Tibetan Texts, History \& Literature of the Himalayan Plateau. Boston: Wisdom, 2001.

Takasaki, Jikidō. A Study on the Ratnagotravibhāga (Uttaratantra): Being a Treatise on the Tathāgatagarbha Theory of Mahāyāna Buddhism. Rome: Istituto italiano per il Medio ed Estremo Oriente, 1966.

Tauscher, Helmut. "Phya pa Chos kyi Sen ge as a Svātantrika." In The Svātantrika-Prāsañgika Distinction, edited by Georges B. J. Dreyfus and Sara L. McClintock, 207-257. Boston: Wisdom, 2003.

Thakchoe, Sonam. The Two Truths Debate. Boston: Wisdom, 2007.

Vaidya, P. L. Bodhicaryāvatāra of Śāntideva with the Commentary Pañjikā of Prajñākaramati. Dharbhanga: Mithila Institute, 1960.

Viehbeck, Markus. "Fighting for the Truth - Satyadvaya and the Debates Provoked by Mi pham's Nor bu ke ta ka." Journal of the International Association of Buddhist Studies 34, nos. 1-2 (2011): 291-320.

Viehbeck, Markus. Polemics in Indo-Tibetan Scholasticism: A Late 19th-Century Debate between 'Ju Mi pham and Dpa' ris Rab gsal. Vienna: Wiener Studien zur Tibetologie und Buddhismuskunde, 2014.

Wangchuk, Dorji. “Was Mi-pham a Dialectical Monist? On a Recent Study of Mi-pham's Interpretation of the Buddha-Nature Theory." Indo-Iranian Journal 55 (2012): 15-38. 
